TRAMES, 2009, 13(63/58), 2, 129-152

\title{
THE ICE PICK OF OBLIVION: MONIZ, FREEMAN AND THE DEVELOPMENT OF PSYCHOSURGERY
}

\author{
Marshall J. Getz \\ University of Houston, Houston, Texas, USA
}

\begin{abstract}
Between 1935 and 1955, psychosurgery was regarded as standard treatment for schizophrenics. Egas Moniz and Walter Freeman had revived it, after earlier experiments led to questionable results. Perhaps the most radical of the biological approaches in psychiatry, it generated controversy after physicians operated on thousands of patients. Claims of its safety and precision met with some resistance, and many who were judged to be relieved had serious side effects. This study traces the role played by Moniz and Freeman in the development of this treatment.
\end{abstract}

DOI: $10.3176 /$ tr.2009.2.03

Keywords: biological psychiatry, Freeman, history of medicine, leucotomy, lobotomy, Moniz, psychosurgery, somatic therapy

\section{Introduction}

The concept of equal rights for anyone other than an upper-class white male is a fairly recent phenomenon. In the latter part of the 18th century, the United States was born out of a rebellion against British monarchy, and in little more than a decade later, the underprivileged population of France launched a revolution that not only changed that country, but destabilized most of Europe. Calls for equality threatened governments, but did not change the fact that certain pockets of individuals remained both disenfranchised and problematic for both conservative and liberal leaders. These groups did not have to be small, since they included women and, of course, the poor.

Perhaps the worst off in any nation were its mentally ill. Then, as now, psychiatric conditions stigmatize those suffering. Until fairly recently, demons or malevolent spirits took the blame for emotional or behavioral differences, while those with the conditions often faced fear or condemnation from their communities. 
One had to be forcefully reminded that the mentally ill or challenged still had humanity about them. 'Cretinism', an antiquated word meaning a certain level of retardation, comes from the French word for 'Christian'. This served as a reminder that the less fortunate did not have to be devils.

Poverty often accompanies mental illness, and the maintenance of those with chronic conditions has always presented challenges. In England, for instance, the concept of mental health did not exist until the 18th century, when King George III's condition deteriorated. According to Henry R. Rollin, the gray eminence of British psychiatry, the doctors who treated this "popular and much loved monarch" helped the field gain acceptance. The newly created state-run institutions could not provide shelter for all who needed help, and many remained homeless, or found themselves sentenced to sweatshops or prisons. This did not mean that residents of these early hospitals fared better than the inmates; Rollin quotes without citing, "... a gigantic asylum is a gigantic evil and figuratively speaking a manufactory of chronic insanity" (Rollin 2000:11-15, quotes from paragraphs 3 and 11).

While psychiatry advanced, mental illness could not be defeated, not in terms of decreasing the numbers of those affected, nor in terms of relieving individuals. Institutions resembled prisons, with barred windows and heavy metal doors. Patients could remain restrained in their beds or straitjacketed indefinitely. Frances Farmer, an American actress, author, early television personality and survivor of a lobotomy, frankly described her many stays in mental hospitals in her 1972 memoir, Will There Really Be A Morning? She recalled a horrific women's unit, where she saw a patient chewing on another patient, who stayed naked and motionless during the attack. Untrained and often brutish attendants did nothing or regarded their charges as animals. Still others preyed on patients themselves (Farmer 1972).

Unlike physical illness, which was either resolved or fatal, a patient could usually survive mental pathology. Dementia praecox, today called schizophrenia, frustrated physicians and psychologists alike. By no means a rare condition, it defied explanation or cures. An eighty- year-old textbook discussed dementia praecox in terms of prevention, and it had limited advice. The authors, Edward Strecker and Franklin Ebaugh, recommended looking for unspecified signs in childhood, making every effort to prepare teenagers for adult life, including working and sex. For those with schizophrenia, treatment included 'safeguarding therapy' - placement in a locked ward, occupational therapy and 'reconstruction therapy', meaning a doctor-patient talk about what the patient could and could not do. The first generation of pharmacological remedies was about twenty-five years into the future (Strecker and Ebaugh 1928:280-281).

Psychosurgery was only seven years away.

\section{Kill it or cure it}

Historians of psychiatry regard psychosurgery as an extreme, or 'last resort' measure, but still keeping within a pattern of increasingly physical approaches to 
mental disorders. This makes intuitive sense, as psychiatrists have a medical background and are trained to combat disease at a biological level. The idea of actually providing therapy to mental patients grew out of the further social changes that took place in two major periods, the years prior to World War I, and then the years between the two World Wars. The upper class of Central Europe produced three physicians who led the movement: Julius Wagner von Jauregg, Ladislav von Meduna and Manfred J. Sakel (Pressman 1998,1-46).

Venereal disease had always been the quiet plague of Europe - quiet in that it rarely became the topic for polite discussion in a society still under Victorian etiquette. While others shook their heads, scientists had been studying it since the 1800 s, at a time when Louis Pasteur and Joseph Lister spoke of germs and bacteria, and the concept of preventative inoculations and even cures. During World War I, the troops of the failing Austro-Hungarian Empire picked up new strains of syphilis from the streets of Belgium and rural communities of Russia. Young men with new infections joined their elders who had picked up the common varieties from the prostitutes of Vienna or Budapest.

The spirochetes of syphilis may enter the body through the genitalia, anus or mouth, but if the patient lives long enough, the disease infects the brain, causing psychosis and paralysis. In 1917, as the war raged, the Austrian neurologist Julius Wagner von Jauregg began injecting an apparently weakened strain of malaria into patients showing the 'paresis' of tertiary syphilis. He had noticed that malaria, which was endemic to the asylums of the time, stopped the symptoms. He enlisted a disease to attack another disease. Probably the malaria created a human environment that endangered the spirochetes, or in plain terms, the resulting fever relieved syphilis. Until effective antibiotics became widely available in the 1950s, Wagner's approach reversed approximately $1 / 3$ of the cases of paresis (Rollin 2000:11-15, Braslow 1997:72-94 and Braslow 1999:5).

This radical treatment caught the attention of the Nobel Committee, which broke with tradition and, in 1927, recognized this neurologist's approach to psychosis as worthy of the Prize in Physiology and Medicine. Wagner's award surprised those who never thought the Committee would find an interest in something as unscientific as psychiatry. Freud never came close (Braslow 1999:5 and Pressman 1998:33).

More important than its recognition, Wagner showed awareness that at least one organic disease caused neurological impairment and psychotic symptoms, and speculated that other mental disorders could be similarly defeated. Braslow further comments that Wagner's treatment actually humanized the way physicians viewed their syphilitic patients. Braslow maintains that patients became more like people again instead of sexually driven creatures left without souls; this author believes that doctors became interested when they no longer saw these patients as terminally ill (Braslow 1997:72-94 and 1999:5).

The Hungarian Ladislav von Meduna noticed that severely psychotic individuals seemed relieved if they also had epilepsy, and most of the chronic patients never had epilepsy. He erroneously believed that the two conditions could not coexist, and 
began 'seizure therapy'. He first used potentially toxic camphorated oil injections, and later tried pentylenetetrazol, commercially known as either Cardiazol or Metrazol, but neither succeeded. Cardiazol induced seizures, followed by devastating muscle spasms and panic attacks. By the 1950s, physicians used curare with the Cardiazol. Curare, a natural muscle relaxant, could ease the spasms, but it was so potentially dangerous that it was the toxin of choice among the indigenous people of the Amazon region (Braslow 1999:5, HUBIN 2002, and Rollin 2000:11-15).

Meduna's work might have fallen into obscurity, had it not been for the studies conducted by Ugo Cerletti and Lucio Bini. Natural and induced seizures resemble an electric outburst in the brain, which inspired these Italian scientists to develop the first electroconvulsive therapy (ECT) techniques. By the early 1940s, 'shock therapy' became the new standard, and Joel Braslow acknowledged that sometimes hospital staff used it as punishment. Some well-meaning physicians enthusiastically treated their patients every six hours, but Braslow, himself a psychiatrist, defended them, as ultimately they regarded this as a treatment, and noted changes in the symptoms of depression - but not psychosis (Braslow 1999:5).

While Meduna explored seizures, Manfred Joshua Sakel adjusted to life in the United States and his new position at the Harlem Valley State Hospital. A Polish Jew who studied both neurophysiology and psychiatry in Vienna, Sakel fled the Nazis and continued his research at Harlem Valley, a facility outside New York City. In 1927, the year Wagner won the Nobel, Sakel found that by lowering the blood sugar in substance abusers and schizophrenics, their symptoms diminished. Sakel began injecting schizophrenic patients with high levels of insulin to cause short-term comas. The normally even-handed Braslow writes that such treatment, "plunged the patient into a coma for several hours 50 or 60 times in the course of several months" (Braslow 1999:5, quote from paragraph 9, Sakel 1958:187-256, and Sabbatini 1997-1998).

Despite the harsh nature of the treatment, Sakel claimed a success rate of $88 \%$, while Braslow pointed out that the insulin injections killed up to $2 \%$ of those treated. This treatment came with a cost, as this labor-intensive method required a certain number of medical staff attending each patient. By the early 1940s, insulin therapy became the standard for hospitals, only to be replaced in subsequent decades by ECT. Apparently, some European hospitals still employ what they call 'Sakel's therapy' instead of ECT (ibid.).

Biological approaches made significant inroads into psychiatric medicine before the 1950s introduced pharmaceutical treatments. They remain controversial due to their risk of organic damage or even death, and yet doctors saw no other way to deal with the tragedy of psychosis. Braslow's writings reflect a reasonable evaluation of these early treatments. Rollin, who would have been taught by psychiatrists working in the heyday of all of these methods, recalls "physical methods...with more shame than pride" (Braslow 1997:72-94, 1999:5, and Rollin 2000:11-15, quote from Treatment paragraph 2).

Most importantly, Wagner, Meduna and Sakel were contemporaries of Egas Moniz, who made brain surgery a viable means of combating mental illness. 


\section{The apes of New Haven}

Psychosurgery did not grow out of the biological movement just described, but merged with it. Trepanning, or cutting holes in the skull, had been done in ancient times and may have saved some lives by easing pressure. The Mayans and Egyptians who chiseled at a head as they would stone had no concept of cerebral pressure. They hoped to create openings for evil spirits, but even in their ignorance, they reported psychological changes after the procedures. In 1848, Phineas Gage, a Vermont construction boss, had his frontal lobes pierced by a large metal rod. He suffered relatively little physically, but he certainly changed mentally. His personality deteriorated, he wandered, becoming irritable and aimless. He changed jobs, living in South America for a time, and at one point, even joining P. T. Barnum's freak show. In an article in The New Yorker in 2001, Michael Specter described him as "the most famous brain patient in American history" (Whitaker 2002:108-111, Fleischman 2002, and Specter 2001:42-53).

Modern warfare led to serious brain injuries. The Germans, who took part in most of the conflicts, had a word for the resulting syndrome: Witzelsucht, or infantile behavior. Damage to the frontal lobes risked the area that gives people their humanity. Nineteenth century researchers knew this. David Ferrier of the United Kingdom operated on primates, while in Italy, Leonardo Bianchi worked on any animals he could purchase from country trappers (Whitaker 2002:109-110).

Experimental vivisection on foxes and monkeys offered little hope for patients with dementia praecox, yet some physicians dared to purposely lesion the brain. No one really understands the quality of cognitive processing in animals, but, depending on the location of the surgery, the behavior could be predictably manipulated. Gottlieb Burckhardt, a physician and chief administrator of an obscure Swiss mental institution, told his staff that psychotic symptoms appeared to be linked to overstimulation in the brain, and this prompted him to try surgery on a handful of inmates from 1888-1889 (Whitaker 2002:111-119 and Kalinowsky, Hippius, and Klein 1982:272-293).

Burckhardt's first patient required four procedures, and he began by cutting into the parietal lobes and eventually impaired the entire left hemisphere. Only then did this patient become subdued. With other patients, he actually performed frontal lobotomies, cutting the connection between the central portion of the brain and the frontal lobes. This immediately resulted in blunting violent schizophrenics into quiet, non-aggressive patients. He later tried operating on the cortex of the temporal region to stop auditory hallucinations, but the surgery did not work. Lothar Kalinowsky and his colleagues suggested that Burckhardt had faith in psychosurgery, but apparently stopped working. Science writer Robert Whitaker believes that since he lost one patient and his others responded little beyond calming down, the Swiss doctor had every reason to discontinue. Burckhardt quickly became forgotten and details of his research murky; Franz Alexander and Sheldon Selesnick wrote that he operated on only one patient in 1890 (Whitaker 2002:111-119, Kalinowsky, Hippius, and Klein 1982:272-293 and Alexander and Selesnick: 1966:157, 284-285). 
Historians of psychiatry agree that Egas Moniz never read about Burckhardt's treatment. Burckhardt probably had minimal influence on the career of Vladimir Bekhterev, the leading figure of Russian physiological psychology in the early 20th century. He had been trained in Wilhelm Max Wundt's premier psychology laboratory in Leipzig, and later studied with Jean Martin Charcot in France. He then established his own laboratory prior to the revolution in St. Petersburg. While Pavlovian conditioning guided his own work, he tried experimental psychosurgery on animals. Bekhterev's student, Ludwig Puusepp actually tried to use brain surgery to treat humans. Puusepp, a pioneering neurosurgeon of mixed Estonian, Czech and Polish ancestry, used a procedure similar to one of Burckhardt's in 1914 on a mental patient. Whitaker, in slight disagreement with Kalinowsky and his colleagues, described Puusepp as operating in 1908 on three patients diagnosed with depression. Puusepp apparently did not continue using this treatment approach when he became a professor and hospital chief in Estonia in 1920. He is much better known for his research on brain tumors and other neuropathology, which made him an icon of the science community in his adopted homeland (Kalinowsky, Hippius, and Klein 1982:272-293, Raudam and Kaasik 1981:85-87, Raudam and Kaasik 1985:283-287, Ljunggren, Bruyn, Käbin and Buchfelder 1998:261-270 and Whitaker 2002:111).

Pioneering work originating in Switzerland or the Russian Empire would not likely catch the attention of the international medical community, nor would it get much support. In the United States, a number of factors came together to make researchers interested in anything pertaining to neuroscience. As in the UK, America had an extensive public health system, along with private facilities, usually for those who could afford them. Public hospitals were jammed with chronic patients. Not surprisingly, the Rockefeller Foundation thought that research on brain function deserved grants (Pressman 1998:47-70).

Through the efforts of John Fulton, the head of the fledgling neurology department at Yale University, Professor Carlyle Jacobsen had Rockefeller Foundation money for advanced primate studies. In the 1930s, Jacobsen had been doing interesting chimpanzee research that became even more interesting after he lobotomized two of them. Adult chimpanzees are amazingly trainable but become easily frustrated. At four feet tall or more and significantly stronger than any human, a temperamental chimp can be dangerous. One of the two had a particularly nasty disposition, but Jacobsen reported that after the surgery, she and the other one no longer cared if they could not perform a task (Whitaker 2002:110-118, 127-130).

Egas Moniz would soon hear about Jacobsen's work, and although the Yale study intended to prove the complicated functions of the frontal lobes in a higher animal, this seemed therapeutic to the Portuguese doctor.

By the 1930s, a growing body of literature showed that any interference in the frontal lobes of a brain caused deficits. Phineas Gage illustrated this, as did the war wounded. Brain surgery failed to help Burckhardt and Puusepp's patients. Sometimes, however, brains had to be violated. By the 1930s, Walter E. Dandy enjoyed a great reputation as a neurosurgeon at Johns Hopkins Hospital. He 
operated on the brain tumor of a young Wall Street executive, identified as Joe A. When Joe A. returned home, he came under the care of Richard Brickner, the equally distinguished neurosurgeon at Mount Sinai (Whitaker 2002:110-118, 127130 and Alexander and Selesnick 1966:157, 284-285).

Brickner documented the case of Joe A., reporting that this patient seemed psychologically better post-surgically, and he did not lose any functioning whatsoever, despite the loss of a portion of the frontal lobe, Joe seemed relaxed and with a preserved IQ. Morris B. Bender, the former Chief of Neurology at Mount Sinai and the departmental historian, praised his predecessor's work, and noted that Brickner eventually became famous for his research on the frontal lobe and its impact on intelligence. While no one wishes to condemn Brickner - he did not perform the operation - Antonio R. Damasio and Whitaker contradict the writings of Bender and Alexander and Selesnick (Alexander and Selesnick 1966:157, 284285, Bender 1973, and Damasio 2000:54-56).

According to Whitaker, many times Joe A. appeared fine, and he certainly did not have the coarseness of a Phineas Gage. A stranger would not have noticed a psychological loss, and he functioned quite normally with familiar material. A closer examination showed impairments. There could be grandiosity, verbal aggression and when given an IQ test, Joe's results did not fit with what one expected from a stockbroker. Nothing about Joe A. should have encouraged Moniz, but he still moved in this direction (Whitaker 2002:110-118, 127-130).

\section{Abreu Freire}

Antonio Caetano de Abreu Freire, known in the history of psychiatry as Egas Moniz (1874-1955), had a career shaped by achievement and disappointments of a grand scale. He had great dreams, and could have become one of Europe's most important physicians, but he could not resist politics and revolution. Born and reared in a quiet town in the north of Portugal, he graduated with a medical degree from the University of Coimbra, which is well-known locally. Before he was forty years old, he became head of the neurology department at the University of Lisbon, a prestigious position for one so young (Lowis and Minagar 2003:286-291).

Today, few realize that Egas Moniz was a nom de guerre, since as Antonio Caetano de Abreu Freire, he was among the most wanted by the Portuguese security forces. Portugal had been on a downward spiral - economically and politically since the 1600s, with the rise of Britain and France. A mainly agricultural country, Portugal remained in the grip of despotic rulers, landlords and the Catholic Church, with a weak military to protect the powers that be from the anger of the masses.

Caetano changed his name to Egas Moniz, or Antonio Egas Moniz, in a futile effort to dodge the authorities. Moniz fought the monarchy as he launched his career, and found himself jailed at least thrice. Being the new Dean of the University of Lisbon's School of Medicine did not protect him from arrest. He would not have political success until King Manuel II fell from power before World War I. During 
the heady days when Portugal seemed free and lacked a stable government, the interim leadership offered Moniz a series of interesting opportunities. He became a legislator, cabinet secretary and recognized foreign policy expert. His reputation increased when, in 1919, he represented Portugal at the Versailles Conference ending World War I. In the palaces of France, the man best known for developing psychosurgery mingled with US President Woodrow Wilson, British Prime Minister David Lloyd George, China's extraordinary Wellington Koo and a young Ho Chi Minh from French Indochina (Lowis and Minagar 2003:286-291, Wiarda 1977: 1-54, 97, and Macmillan 2003:45, 57, 59, 331-334).

Lowis and Minagar described Moniz as a very prolific researcher, although he truly dedicated himself to medicine after the age of fifty. He wrote over 100 journal articles and three books in just more than a decade. He might not have returned to medicine if, in 1926, a military junta seized power in Lisbon. The Salazar regime jailed Moniz once again, and ended a flamboyant political career. Past sixty years old, Egas Moniz may not have been clinically depressed, but he was certainly disappointed. He felt that despite all he had done, he had not really met his potential. He decided that what he really wanted out of life was the Nobel Prize (Lowis and Minagar 2003:286-291, Whitaker 2002:110-114, and Wiarda 1977:1-54, 97).

Moniz is remembered as the father of psychosurgery, and more professionals remember that he invented cerebral angiography in the late 1920s. Lowis and Minagar noted that what has been forgotten is that he also established the diagnostic categories of vascular disease of the brain, particularly the occlusion (blockage) of the internal carotid artery. Using angiography as a technique frustrated Moniz, since he had difficulty finding the proper chemical for radiographic imaging. Some deaths from failed attempts left him in despair, until, in 1927, he found the exact solution of sodium iodide. By the early 1930s, Moniz knew that cerebral circulation could be distinctly changed depending on the specific pathology. He began reporting on special psychiatric issues, including word-finding difficulties and mood swings. The neurological consequences of an arterial blockage could include limited paralysis and partial blindness. Still, the coveted Nobel Prize eluded Moniz, although he was shortlisted in 1928 and 1933 for this research. Apparently, he actively campaigned for the Nobel with the same gritty drive that one might see in a Hollywood producer anxious for an Academy Award. Whitaker actually accused Moniz of purposely condemning worthy research in his active correspondence, hoping the panel in Stockholm would favor his work (ibid.).

Life might not have changed for Moniz, had he not traveled to the Second International Congress in Neurology in London, in the summer of 1935. He had had little to do with psychiatric issues, other than those resulting from carotid artery pathology. He had been isolated, at times in prison, unaware of Burckhardt, Bekhterev and Puusepp, and the world did not know much about him, since he published mainly in Portuguese. Moniz heard many papers on frontal damage, including a discussion of Joe A. by Brickner, and a paper about Jacobsen's docile chimpanzees. If the point of this conference was showing how damage to the 
frontal lobes causes pathology, Moniz took away a different message: this damage had therapeutic value (Pressman 1998:52-58 and Whitaker 2002:110-114).

Moniz returned to Portugal thinking that psychosis might actually be in the neural fabric itself. Strange ideas could actually be held at the cellular level, or, in his words, 'celluloconnective systems' (quote from Whitaker 2002:113). He then decided that this fabric could be shredded with an instrument. Damasio wisely pointed out that no research at the time had shown that 'overactive circuits' create psychotic symptoms, nor had any experiments resulted in improvements. At a time when imaging remained primitive and microscopes qualified as antiques, Moniz did not see emotional or thought disturbance as a problem with the gross pathology of the cortex or the rest of the brain. He became fascinated by rumination among schizophrenics, and believed that cutting off the thalamus from the frontal lobes would disrupt obsessive thinking. Both parts handle information processing of sensory input (Damasio 2000:59, also see Alexander and Selesnick 1966:157, 284-285).

From 1935 to 1936, Moniz perfected a procedure he called the "prefrontal leucotomy'. As the name suggests, the surgery involves sectioning the white matter. He could not actually operate, since he had arthritis since the 1920s. For the actual surgery, he turned to his assistant, P. Almeida Lima, who presumably carried out all of the leucotomies. The first subject was a woman in her 60s, a psychotic likely sentenced to a mental hospital for prostitution. Lima did this procedure, which involved 'coring'. This meant piercing her skull with a bone drill, then killing nerve tissue with a hypodermic needle filled with alcohol. The attending psychiatrist was apparently pleased, probably by her new manageability (Damasio 2000:58-60, Lowis and Minagar 2003:286-291, Whitaker 2002:110-114).

Moniz and Lima moved on to nineteen other patients, and began using a leucotome, an instrument that resembled an ice pick or probe. They experimented using more and larger lesions, discovering that the procedure did not help the symptoms of psychosis, nor did it improve obsessive-compulsive disorder. They did note success with affect, although many considered these patients depersonalized. They had been severely ill, and had not improved with other therapies. This was reason enough for Moniz to be pleased with himself, and he began publishing almost immediately (Alexander and Selesnick 1966:157, 284-285, Kalinowsky, Hippius, and Klein 1982:272-293, Pressman 1998:53-58 and Whitaker 2002: $110-114$.

In 1937, Moniz published an article on his second series of psychosurgery patients, much of it three case histories. He briefly described the procedure, and mentioned some immediate post-surgical issues. Chief among these were eye movement disturbances, which faded as the patient recovered. The stories of these patients fascinate any researcher. The first was a woman in her 30s, who had been psychotic for almost a decade. Married with children, she decompensated while living with her family in the Belgian Congo. This woman had a family history of mental illness, and once had a miscarriage. She believed that something happened to her healthy daughters, that they were either burned or cut up. She tried to kill 
herself, using acid and by hanging, and on the ship back to Portugal, she was found carrying weapons. In the hospital, she believed the nurses to be ghouls and saw visions of blood. After the operation, she said that she felt better and wanted to raise her children again (Moniz 1994:236-239).

Moniz's next patient, a policeman in his 30s, entered the hospital with 'psychomotor agitation', would not eat nor rest, and became paranoid about the hospital staff. After his surgery, he retuned to his family. The third case study, of a male in his 30s, followed a similar line. He ran a newsstand, but also abused alcohol and heard voices. As he worsened, religiosity became a theme, and he blamed the radio for the disturbing voices. When his movements became wild, his speech incoherent, and he no longer knew his family, he was hospitalized. There, he beat an orderly. After his leucotomy, he became calm. They all did. Most importantly, the hospital discharged all three patients (Moniz 1994:236-239).

Moniz felt encouraged enough to write, "The recoveries have been maintained. I cannot believe that the recoveries can be explained upon simple coincidence. Prefrontal leucotomy is a simple operation, always safe, which may prove to be an effective surgical treatment in certain cases of mental disorder" (Moniz 1994:239).

Diane C. Gooding, William G. Iacono and Daniel R. Hanson might disagree with the flippant attitude Moniz showed toward those eye movement abnormalities. While both smooth pursuit (tracking) and saccades (scanning movements) tend to be different in schizophrenics, their single case study challenged what Moniz believed. Testing a 67-year-old schizophrenic woman who had a prefrontal leucotomy at age 31, she still had paranoid symptoms and a history of many post-operative hospitalizations. An MRI showed that the operation had been done. Using an infrared light to track her eye movements, the authors found nothing abnormal about her smooth pursuit, but her saccades tasks varied. She gave abnormal responses on her antisaccades exercises. While this is frequently found in schizophrenics, her scores appeared extreme. They suggest her $80 \%$ error rate would be more likely the result of brain damage than psychosis (Gooding, Iacono, and Hanson 1999: 462-467).

Braslow offers his support, saying that Moniz's psychosurgery "was arguably the most scientifically legitimate of all these somatic treatments". Braslow also pointed out that one needs to consider the availability of scientific knowledge at the time. In the 1930s, most of the medical community still did not know of Moniz's research. Although in 1936, Moniz presented at an international conference, his experimental procedure did not impress many, although there was some interest in Italy and other neighboring countries (Braslow 1999:2; also see Kalinowsky, Hippius, and Klein 1982:272-293).

Moniz's more significant work on the carotid artery would not be published in English until 1947. That was a key year for him, since Lisbon hosted a convention of British neurosurgeons. The aging physician, a legend in his country, talked about the difficulties of radiographic imaging of the brain, mental illness and what the future might hold. He sat in a wheelchair, a paraplegic since 1939, when a patient shot him. Moniz's role at the convention helped his cause, and in 1949, he 
finally won the Nobel Prize he desired for so long. He had 'retired' in 1944, but certainly did much in the last eleven years of his life. He saw patients, wrote about neuroscience and culture, and at the time of his death, worked on an apparently lost study of an experimental surgery for Parkinson's disease (Lowis and Minagar 2003:286-291 and Whitaker 2002:110-114, 130-138).

\section{Across the Atlantic}

Much of what Egas Moniz had been doing to psychiatric patients raised eyebrows at a time when most viewed these patients as social problems with limited rights. American democracy granted far more freedom than the Salazar government in Lisbon, but minorities did not share the same status as whites. The poor remained powerless, and the residents of mental hospitals grew in number. Distinguished journalist Jack El-Hai puts it best when he writes, "Between 1903 and 1933, American psychiatric hospitals more than doubled in size, and some ...swelled into vast complexes of nearly ten thousand patients. Even into the 1920s, hospitals lacked treatments that healed, or even helped, many patients, and institutions ...had grown into huge warehouses of the sick. Snake pits, hell holes, institutions of despair - they were called many things, but psychiatric hospitals of the 1920s really could do little for patients with mental disease except house and feed them until there was a spontaneous remission, which occurred with some frequency" (El-Hai 2005:60).

It was into this discouraging area of medicine that an unlikely figure would make an impact, stealing European dominance of biological treatments of the mentally ill. Walter Jackson Freeman (1895-1972) came from a distinguished Philadelphia family. English ancestors dated back to the ships that came to Colonial America just after the Mayflower, while his mother's German clan raised their broadswords in the Thirty Years' War. More immediately, his maternal grandfather, W. W. Keen, had been one of America's leading surgeons, and Freeman's father had a thriving earnose-and throat practice - but hated it. Other relatives took the lead in East Coast business (El-Hai 2005:18-32)

Had Freeman been a student today, he would be described as a 'nerd' or 'geek' . Pressed by a mother he resented and the eldest child in a large family, he failed at sports, music and dating. He found pleasure in photography. Freeman caught every childhood illness, and his father, who often joked about his surgeon father-in-law, happily turned the boy over to him. As an undergraduate at Yale, he barely survived a bout of typhoid, made middling grades, but earned a reputation for daring by snapping a photograph of a secret society's moonlit antics. A paparazzo before his time, he sent the picture to The New York Times, but the Gray Lady spiked it when outraged Yalies threatened to call their lawyers (El-Hai 2005:33-60).

As a child, Walter Freeman spent summers in the country or cruising the West Indies and Latin America. As a solitary young man, he worked summers in a New England power plant, ignoring his job but developing his concentration by doing 
mental calculations. Ignoring the machinery proved risky, and he ruined at least one piece of equipment. He intended to be a physician, but enjoyed making money and spending it on cameras and clothes (El-Hai 2005:33-60).

Returning to Philadelphia during World War I, he took his medical education at the University of Pennsylvania. Like most medical students at the time, Freeman joined a medical army reserve unit, so he technically went to classes in uniform. Ever awkward, El-Hai noted that laboratory mishaps made Freeman's uniform look battlefield-scarred. In medical school, Freeman fell in love with a promising woman - and promptly lost her to a bon vivant and world affairs expert named Allen Dulles. While Freeman earned a reputation for psychosurgery, Dulles became America's chief intelligence officer (El-Hai 2005:33-60).

As the First World War came to a close, mankind found itself under siege by nature. From the brown-water rice paddies of southern China, influenza jumped from poultry to swine to man, and the epidemic spread around the world. In 1918, all physicians learned epidemiology firsthand, and Freeman served in flu wards. He later had a rotation in what would later be called emergency room medicine, but he did not find a specialty until he helped treat a man with an organic brain disorder. Freeman then decided to train as a neurologist (El-Hai 2005:52-62).

In many ways, Walter Freeman was the American version of Egas Moniz. Twenty years younger than the Portuguese, he was secretly discontented, but not with neurology. He did not covet the Nobel, but he wanted fame. Losing his professional and social clumsiness, he became a prominent researcher. He served as a committee member of two national boards and was known for his text on brain pathology. A colorful professor, "he taught his classes with a theatrical flair, mesmerizing his students, in particular with in-class autopsies. Freeman would remove a corpse's skullcap with a saw and then triumphantly remove the brain, holding it up to teach neuroanatomy" (Whitaker 2002:115).

When he discovered what Moniz was doing in Portugal, Freeman found his niche. Whitaker put it well, writing, "[Lobotomy] had a natural allure for him - it was bold, daring, and certain to ruffle a few professional feathers" (Whitaker 2002:115). Moniz's research excited him to an extent, but Freeman had his own theory of psychiatric therapy, and predicted that the field would turn to surgical approaches. He did not address 'celluloconnective systems', but believed that if pathology destroyed tissue causing symptoms, why not alter the brain for positive change? Moniz was competition, and Freeman would move beyond him. But he could not understand why the medical community forgot the ill-fated experimental surgery of Gottlieb Burckhardt.

\section{The American lobotomists}

Perhaps to keep Moniz from gaining too great a lead in this radical new movement, Freeman and James Winston Watts, his favorite colleague, operated on September 14, 1936. This first American lobotomy took place as Moniz began to 
publish, and it would be Freeman who would be responsible for the medical community outside Italy and Portugal showing any interest in this procedure (Kalinowsky, Hippius, and Klein 1982:272-293). Freeman's first patient was an old woman like Moniz's, but leading a completely different life. A married woman diagnosed with an unspecified affective disorder, her physicians considered her at risk for suicide, but Freeman described her as a 'master at bitching', and both he and Watts pitied her husband. They almost jokingly remembered that this patient only worried about needing a preoperative shave. They lied and said they would not touch her hair. They cheerfully reported that when she woke up bald, she did not care (Freeman and Watts 1950:xviii).

The fact that they saved an obviously distressed woman was reason enough to be proud. Subsequent evaluation showed her humanity still remained intact, with memories untouched and general appreciation of life still there. An indication of the later controversy showed up in this first patient; the doctors noted that her 'sparkle' was missing. This did not discourage them, and by November 1936, they had done only six lobotomies, yet enthusiastically began presenting at conferences (Whitaker 2002:116).

Freeman took the true initiative in promoting psychosurgery, and enlisted the popular and professional media. His grandfather Keen, despite a hectic schedule, always wrote articles about health for the mainstream press, and kept his name in the public arena. Freeman began a relationship with a journalist named Thomas Henry, who wrote for the Washington Star, but more prestigious periodicals followed, including Time, Newsweek and The New York Times. With the press, Freeman speculated that brain surgery would be developed to cure physical illness even in other areas of the body. He said that people wrote begging for the procedure, while others encouraged him and his partner to go further with it. Whitaker quoted one would-be poet, who penned a testimonial to Freeman and Watts: "They cut so sure they serve so well/They save our souls from Eternal Hell." This poem ends with a reference to being "saved" and "free" (Whitaker 2002:116-121 and El-Hai 2005:111-177; the poem appears in Whitaker 2002:119 and El-Hai 2005:171).

James Watts had more prominence than Almeida Lima, Moniz's collaborator, and a reputation in his own right. Watts came from a well-off Virginia family, and like Freeman, had a physician for a grandfather. When he graduated from the University of Virginia with his doctorate in medicine, he interned in neurosurgery in Illinois, and did postdoctoral research in Europe (El-Hai 2005:88-93).

El-Hai points out that in a roundabout way, Freeman's grandfather paved the way for the successful Freeman-Watts partnership. Keen mentored a young Harvey Cushing, a surgeon who, in the first quarter of the 20th century, dreamed of cutting into the brain to remove tumors and repair injuries. Keen encouraged him to try, and he became a pioneer, eventually joining the faculty at Harvard Medical School. Cushing taught John Fulton, whose specialty was physiology, and who took over Yale University's neurology department and primate laboratory. Fulton directed important scholarship at Yale, including Jacobsen's surgery on 
chimpanzee brains, and he brought Watts to his team (El-Hai 2005:88-93 and Pressman 1998:58-76).

In the early 1930s, Watts met Freeman through professional conferences, when Freeman's research interests had moved to multiple sclerosis. Freeman liked him, and by 1935, lured him to George Washington University. Watts was not only familiar with psychosurgery, but 'befriended' one of Jacobsen's lobotomized chimps. El-Hai noted that his rapport with the primates paralleled his easygoing relationships with psychiatric patients. Freeman tended to be as wildly charismatic as a Barrymore onstage, while Watts gave a workmanlike performance as a professor. With the apparent exception of their textbook and one article, Freeman did all of the writing - usually as sole author (El-Hai 2005:88-93).

\section{What did they do?}

Lothar Kalinowsky and his colleagues would not have likely admitted this, but from the way they describe the heyday of psychosurgery (1935-1955), the physicians did not really know what they were doing. Kalinowsky himself had a reputation among proponents of psychosurgery, but made his name as a developer of ECT. They suggest that Freeman and Watts had done their research, and obviously had a vested interest in a more accurate approach to localization theory. The early scholars could not exactly map brain functions, but they knew that most of what makes people 'human' rested in the frontal lobes. By 1937 - two years after Moniz's first patient - neurologists knew about Papez's circuit, and began to determine the role of the limbic system in processing emotion (Kalinowsky, Hippius, and Klein 1982:272-293, Freeman and Watts 1950:23-54 and Pressman 1998:73-113).

Still, there were problems with the research of the day. Most articles reported studies using monkeys or apes, and reports on humans offered information on gross brain pathology, such as trauma or cancer. The lobotomy had to be a 'blind' procedure, which was further complicated by the fact that proponents of psychosurgery debated over the extensiveness of the lesioning required. Freeman and Watts later discovered that doctors did not need extensive cutting to impact patients' behavior and emotions (ibid.).

Within a few years, Freeman, Watts and a few others altered the Moniz prefrontal leucotomy, with varied results. Freeman and Watts began with the Moniz procedure, but quickly developed the standard lobotomy. Another blind procedure, the doctor would need to drill into the skull, in the area of the coronal suture and glabella (top of the forehead). Using a sharp-ended tube called a cannula and a leucotome, the doctor supposedly made 'sweeping movements' and 'stab incisions'. This would be done on both sides, and possibly with the patient awake. If the patient was too uncontrollable, procaine (an early version of Novocain) or full anesthesia could be used. Freeman did not invent the transorbital lobotomy, but certainly made it popular. In 1937, the Italian researcher Fiamberti used it for 
exploratory brain surgery. Its ease attracted Freeman, since it "can be performed by the psychiatrist himself". The leucotome could reach the frontal lobes by going under the eyelid and pressing against the eyeball. Freeman and Watts advocated using ECT as the anesthesia for a practical reason - a psychiatrist would be more comfortable with this rather than a chemical method. Also, in Freeman's conceptualization of mental illness, ECT would break up the pathological thinking, then the anatomical changes of lobotomy would keep the thinking from being restored (Freeman 1949b:734-740; quote from Kalinowsky, Hippius, and Klein 1982:278-279).

Other physicians suggested different procedures, including the cingulotomy, which was done with a precise mechanical instrument called a stereotaxic device. Others spoke of chemical lobotomies, following Moniz with alcohol injections, but later turning to Novocaine. Here, the goal was to make brain tissue die. The more technically-oriented suggested using ultrasound, believing that behavior could be changed without destroying tissue (Kalinowsky, Hippius, and Klein 1982:272-293). Matthew T. Moore of the University of Pennsylvania and Philadelphia Psychiatric Hospital had no argument with the transorbital lobotomy, but objected to the leucotome. He felt that it was too awkward to use, and could get 'lost' in the brain. Moore recommended the transorbitome, a dual-bladed probe that resembled giant tweezers (Moore 1949:741, plates 9 and 10).

Others debated over whether the surgery could be done more than once. The general consensus held that if an extensive lobotomy had already been done and did not work, another major procedure could go deep enough. Any number of minor procedures following an unsuccessful one would probably not affect the patient (Freeman 1967:1450-1452, see also Kalinowsky, Hippius, and Klein 1982: 272-293).

Decades later, the use of imaging techniques and electron microscopes allowed medical researchers to know the very nature of a surgical lesion. Arai, Tsutsui, Shinmura, Kosugi, Nishikage, and Yamamoto described their 1997 autopsy of a 69year-old homeless man who collapsed and died in an emergency room. An investigation showed that he had been a schizophrenic who had a lobotomy at age 37, in 1964. The pathologists found no gross pathology, such as scarring or atrophy, but after sectioning, they discovered "bilateral cystic lesions with a smooth surface in the white matter of the frontal lobe." The tissue in the area was "thinned and destroyed," with nerve tissue actually gone and demyelinization detected. The researchers stated that this atypical damage does not prove lobotomy, but suggests what might be found when studying the brains of older mental patients (Arai, Tsutsui, Shinmura, Kosugi, Nishikage, and Yamamoto 2001:53-60, quotes from 54 and 55).

By 1949, Freeman committed himself to the transorbital lobotomy. Any kind of 'coring' would automatically be too extensive, and he found that disturbing the limbic region did not help. Results came from manipulating Broadmann's Areas 9, 10 , and 46 , and the transorbital lobotomy provided the necessary lesion with the minimum of cutting. He mentioned bleeding from the eye and temporary hemi- 
paresis (weakness on one side) as the common risks. Freeman noted that in over 500 patients he and Watts worked on, $20 \%$ were unsuccessful. He blamed most of the failures on patients having been operated on too late, the schizophrenia having progressed too far (Freeman 1949b:734-740, see also Valenstein 1973:54-55).

Having been operating for more than a decade, Freeman seemed uncertain about clear indications for psychosurgery. While schizophrenics made up the bulk of the patient population he worked on, he and Watts discovered that not all types responded equally well. The paranoids often improved, while catatonics did not. The psychotic symptoms - hallucinations and delusions - often remained unchecked by lobotomy, but mood and anxiety issues, such as the depressive, obsessive-compulsive and 'neurotic' features that often accompany schizophrenia - were relieved. Most importantly, violent behavior often stopped immediately. This would have a tremendous impact on its use in institutions. Despite its effectiveness with aggression, Freeman claimed that it would not help criminal violence, antisocial behavior or substance abuse (Freeman 1950:534-535 and 1957:877-886).

In a 1949 article for the American Journal of Psychiatry, Freeman recommended that patients be operated on within one year of diagnosis for the best results. He also suggested that if ECT worked on a patient, he or she would be a likely candidate for the transorbital lobotomy. He described the case of a catatonic schizophrenic whose symptoms troubled her for three years, and who had some help from electroshock. After her surgical procedure, she was working again within two weeks (Freeman 1949b:734-740).

This particular article concluded with a discussion by Mary Frances Robinson, a psychologist. She tested surgically treated patients at the state hospital in St. Joseph, Missouri, and found what could have been considered less than optimal results. After assessing less than 90 patients, she found that most had signs of 'frontal lobe deficit'. They could no longer concentrate, had limited affect, appeared unmotivated and lost interest in their own lives. Far more than 'sparkle' seemed missing. Yet Robinson wrote, "Psychologists are notoriously conservative and sceptical, and lag far behind the more progressive psychiatrists. ...For a long time, I even objected to shock treatments, but I got over that. I objected more strenuously to prefrontal lobotomy. I felt strongly that functional mental illnesses should be treated by mental methods". Yet after seeing patients, she decided that psychosurgery had been warranted (Freeman 1949b:740).

Robinson was one of the few psychologists to advocate lobotomy as a viable treatment. With a Ph.D. from the University of Chicago, she studied under Freeman and became a professor at St. Joseph Junior College, but did pro bono work and research at St. Joseph State Mental Hospital for thirty years (Missouri Western Library s.a.). Four years earlier, she co-authored an article with Paul Schrader, reporting on a small study, but one of the few scientific efforts at the time. Using sixteen patients who had been operated on at St. Joseph in 1943, they had nurses and orderlies rate them on the Gardner Behavior Chart, a simple checklist developed at another hospital in the mid-1930s. It looked at such issues 
as appearance, work, and activity levels, and was completed before and after each patient's lobotomy. While most writers at the time commented on the possibilities of release, this was not their concern. They found that on average, patients improved on each category $(\mathrm{M}=1.28)$. Additional testing showed no changes in the patients' IQ scores (Schrader and Robinson 1945:61-69).

Writing in the Journal of Nervous and Mental Disease, Freeman warned that failed surgeries might be the result of cutting too deeply, or, as he put it, "Incisions made far posteriorly [sic] in the frontal lobes are eventually fatal, either from inertia or from visceral and trophic disturbances" (Freeman 1949a:413-418, quote on p. 414). He described bizarre symptoms, such as patients who could move but not sit, or those who tried to eat but could not swallow. Most tellingly, he discussed postoperative symptoms that many critics had already raised, such as binge-eating, awkward romantic or sexual ideas - ill-timed and acted on - and non-existent selfcare and hygiene. All of these, he blamed on posterior incisions. Freeman accepted that lobotomy wiped out creativity. "None of our patients has written a book, designed a house, composed a piece of music or invented a salable gadget". Talk among enthusiastic psychiatrists and neurosurgeons that creativity remained was discounted by Freeman, who said that anything creative was likely residual psychosis or something considered before the operation (ibid., quote on p. 416).

Despite Freeman's warnings, doctors performed lobotomies on various types of patients, with, naturally, mixed results. At Fairfield State Hospital in Connecticut, researchers followed the results of 107 lobotomized patients, aged 18-64, who had been treated due to management problems. For many, psychosurgery had not been a last resort, but a reaction by the medical staff to unruly behavior. In a setting reminiscent of One Flew Over the Cuckoo's Nest, the procedure seemed to be a form of punishment. Going against Freeman, many patients who had not responded well to ECT received surgical treatment. Evaluations were based on symptom relief only, and one of the surgeons co-authored the study. They found that $30 \%$ of their patients could be regarded as symptom-free, and most of them had been diagnosed as paranoid schizophrenics. The investigators viewed the negative symptoms, such as a decline in hygiene and emotional numbing, as improvements over prior behavior (Oltman, Brody, Friedman, and Green 1949:742-751).

Misuse of the transorbital lobotomy becomes understandable, if not something to be condoned, when one considers the historical context. The press ran with success stories, many of them planted by Freeman, and the public was misled into believing that psychiatrists and neurosurgeons pushed their leucotomes with simple elegance and precision. Even after psychosurgery had its run, fears about its revival persisted. The 1960s saw chaos and violence in America, and the Watergate scandal of the 1970s showed that not all of American leadership could be trusted. In his 1978 diatribe, The Mind Stealers, Samuel Chavkin interviewed police and urban officials, and suggested that 'the government' wanted psychosurgery as a means of repressing teenagers, minorities and social misfits (Chavkin 1978, Valenstein 1973:253-263, 342-353, and Diefenbach, Diefenbach, Baumeister, and West 1999:60-69). 
In their study of how journalists covered psychosurgery, Diefenbach, Diefenbach, Baumeister and West discovered that the procedures, especially the transorbital lobotomy, had a reputation for being simple enough to warrant training a psychiatrist, rarely caused fatalities, and saved lives. The public heard less about surgical approaches in the $1950 \mathrm{~s}$ - as antipsychotic drugs reached the market (Diefenbach, Diefenbach, Baumeister, and West 1999:60-69).

With the media attention, even the famous could not resist seeking help from this radical 'cure'. In the 1940s, the Kennedy family already enjoyed a reputation for wealth and power that had grown far beyond their Boston roots. The father, Joe Kennedy, made a fortune in a variety of businesses, served as Franklin D. Roosevelt's ambassador to Great Britain, and openly groomed his sons for greatness. The family had a number of secrets, including the eldest daughter, Rosemary, born in 1918, at the height of the influenza epidemic. Accounts vary, but she suffered from mental retardation, with journalists Harrison Rainie and Katia Hetter describing her disability as 'mild', while presidential historian Robert Dallek wrote of her being 'tragically retarded'. As Rosemary matured, she became aggressive and Kennedy feared that she would become pregnant. In 1941, he had her lobotomized without discussing it with his wife, Rose. Moniz and Freeman never suggested psychosurgery being used on retarded patients, and this procedure did not go well, with Rosemary left unable to care for herself. The family sent her to a convent in Wisconsin, where she lived until her death in 2005 (Rainie and Hetter 1993:44, Dallek 2003:22, and Associated Press 2005).

In the 1930s and 40s, a pretty blonde named Frances Farmer left her small town and, like a cliché, approached Hollywood to make her a star. She did appear in a few B-rate films, but unlike the majority of young people who migrate to that part of California, she had a social conscience. Attracted to the Soviet Union and known to appreciate leftist causes, her life was further complicated by irritability on the set and turbulent relations with her family and lovers. Her mother institutionalized her, and later she had a lobotomy. She worked afterward and wrote her life story, but the old 'sparkle' was obviously missing (Clifford 1982).

When considering the ranks of the troubled famous, one ironic exception stands out. While Farmer scandalized her mother by raising money for Stalin, Ezra Pound promoted fascism. Pound, an Ivy League-educated poet and critic, railed against FDR while living in Mussolini's Italy. When he returned to the US as a prisoner, the federal government charged him for conspiring against America, but the courts found him insane. Spared a reading before an executioner, the government sent Pound to St. Elizabeth's Hospital in Washington, D.C. Freeman and Watts worked there, yet no record suggests that this difficult individual was operated on (Wilmer s.a. and Menand 2008).

In 1952, the French pharmaceutical company Rhone-Poulenc changed psychiatry by introducing phenothiazine (chlorpromazine) as a means of controlling psychotic symptoms. By that time, Freeman and Watts had performed over 600 surgeries, and about 5000 patients in America's institutions received this intervention annually. In the 1970s, distinguished neuroscientist and critic Elliot Valenstein bemoaned the 
problems in finding reliable records for lobotomies performed. He wrote that the pair had 1000 patients, and had some involvement in approximately 3500 procedures. Valenstein suggested that during the decades when this treatment was in vogue, 40,000 Americans were psychosurgery patients (Pressman 1998:147, Rollin 2000:11-15, Whitaker 2002:121, and Valenstein 1973:55). As with lobotomies, the first generation of drugs had side effects, some severe, but the medical community saw them as remedies for mental illness. No longer did doctors speak of discharges, but of removing the bars from hospital windows.

Despite Chavkin's fears, psychosurgery found an enduring place in psychiatry, and not as a means of control. H. Thomas Ballantine, Jr. of Harvard Medical School and Massachusetts General Hospital, a prodigious researcher who pioneered ultrasound techniques, did not invent, but strongly advocated using stereotaxic procedures to relieve some forms of depression and obsessive-compulsive disorder. This technique became available in the 1970s, and in its day, was precise. Although this was deep-brain surgery, it was not linked to any fatalities; however, legendary scholar Hans Teuber and his team from the Massachusetts Institute of Technology investigated this work, but did not find the strong results Ballantine had produced (Harvard Medical School 1996).

In the years since most leucotomes were dropped into forgotten drawers or put into display cases, a few surgeons continued with invasive procedures, but for highly specific and virtually intractable cases. As one reads the professional literature, one must be careful to note the time when physicians used psychosurgery for certain conditions, and for how long. In the main, surgeons abandoned lobotomy, but they performed cingulotomy, which involved lesioning the cingulate gyrus with electricity. More recently, imaging and computer circuitry have allowed a new form of psychosurgery to be developed, called neuromodulation, or deep brain stimulation (DBS). Surgeons wire a 'brain pacemaker' into the cortex, so controlling a number of symptoms (González 1980c:2141-2143, 2146-2147, Cleveland Clinic Foundation 2005:22-26, and Lamberts 2000:87).

Neuromodulation differs greatly from both lobotomy and cingulotomy. Implanting the electronic device requires surgery, but it does not cause permanent change, unless it is left in place. The procedure was initially developed to relieve movement-related symptoms in Parkinson's disease, but early experiments with depressed and OCD patients seem promising (Kuehn 2007:2249-2251). Austin E. Lamberts described the use of brain procedures to relieve debilitating chronic pain. Some earlier reports on pain treatment did not support its use. In 1980, Elizabeth Rasche González discussed operating on patients for pain, and quoted a researcher, Dorothea Z. Lack. According to González, Lack commented, "It's a very simplistic approach to a very complex problem. I can't think of a word that's bad enough to describe it" (Cleveland Clinic Foundation 2005:22-26, Lamberts 2000: 87, and González 1980a:2147).

González seemed at odds with Lack, referring to Ballantine's above-mentioned cingulotomy study, which suggested that it could help those with chronic pain, as well as patients with the symptoms of depression. She indicated that this procedure 
should not have been used for those with anxiety disorders or psychosis (González 1980c:2141-2143, 2146-2147).

In a March 2009 letter to the Journal of Neurosurgery, Harold A. Wilkinson shows how far surgery has come. He refers to a 1999 study which he led, using cingulotomy for chronic pain. Following some patients for a decade, he reported that some had 'sustained pain relief', and he mentioned the value of the permanence of lesioning over the need for battery maintenance with a DBS unit (Wilkinson 2009:607).

Stereotactic radiosurgery targeting specific major nerves has been used for severe jaw and facial pain, with fairly positive results. Here, neurosurgeons use a Gamma Knife to deliver a controlled dose of radiation. The surgical aspects relate to the placing of the stereotactic equipment, with the radiation causing the lesion. A recent report from France suggested that the Gamma Knife procedure can relieve nerve pain, but may need to be repeated. Its chief asset is the low risk of injury or infection (Yomo, Arkha, Donnet, and Régis 2009:559-563, and RadiologyInfo 2008).

Here, a distinction should be made between procedures that deal with nerve pathology, such as the Gamma Knife, and those that target pain-processing areas. Cingulotomy and lobotomy had more to do with adapting the brain to pain, rather than blocking the nerve. When one hears that a patient no longer is troubled by symptoms after a procedure involving the frontal lobes or deeper areas, one has to consider if the patient's mental state has been altered, rather than a symptom diminished.

Attempts to use psychosurgery for conditions other than chronic pain or depression have been generally unsuccessful, but with increasing precision, improved results could be a reality. González raised the issue of psychosurgery being considered for anorexia nervosa, but apparently not in the US. She also mentioned attention-deficit/hyperactivity disorder as another condition that had been considered suitable for psychosurgery (González 1980b:2245-2247, 2250-2251). Fred R. Volkmar briefly noted in an editorial to The New England Journal of Medicine that surgical approaches were once 'considered' for autism (Volkmar 1999:1842-1844). In 2001, Joseph Jankovic described surgical techniques for relieving the tics associated with Tourette's syndrome. He indicated that stereotactic procedures did not work, but he found a case study in which neuromodulation yielded some help for the patient. Jankovic acknowledged the difficulties with Tourette's patients, who sometimes show the symptoms of obsessive-compulsive disorder. In homage to Jack Pressman, he said that in these cases, a lobotomy or cingulotomy would be a 'last resort' (Jankovic 2001:1184-1192, quote on p. 1190).

History is at the frontier.

\section{Discussion}

For approximately two decades, the various forms of lobotomy became the standard treatments for the mentally ill, particularly schizophrenics. While Egas 
Moniz and Walter Freeman, the leaders of the movement, pressed ahead, not all in the medical community accepted what they proposed. Lesioning the brain affected emotions and behavior, but they tended to be flippant about the side effects. Whitaker openly accuses Freeman of dishonesty, while Pressman and Braslow tend toward moderation. Any history of this procedure might gravitate toward the gory, but Pressman and Braslow do not lose the context of the times (Whitaker 2002:121-136, Pressman 1998:47-146, and Braslow 1997:125-135). For this reason, Pressman's Last Resort earned high praise from The New England Journal of Medicine. The reviewer pointed out Pressman's consideration of research standards of the time, and appreciated the author's warning that mistakes can be made today (Eisenberg 1998:1719-1720).

Did Moniz see success where it did not occur? Did Freeman forget to mention that some patients became hypersexual after a lobotomy? To defend the lobotomists in 2009 is a difficult task, and the nature of psychology is to promote all forms of talk therapy. Still, what made Edward Strecker, the lead author of the 1928 psychiatric textbook cited earlier, change his mind? In 1928, the Philadelphia psychiatrist and his colleague wrote about using talk therapy for dementia praecox, but Whitaker described him as one of Freeman's major disciples. When Freeman himself grudgingly acknowledged less 'sparkle' in some patients, Strecker did not accept that. He found more humanity in the patients he operated on, and would no longer consider talking to a schizophrenic until he or she had been lobotomized (Strecker and Ebaugh 1928:280-281 and Whitaker 2002:120).

This author believes that the mental health community in the 1920s, 30s and $40 \mathrm{~s}$ had an even greater struggle than what professionals face today. If one looks beyond the obvious abuses, one finds an immense population of very ill people. Like the physicians dealing with the flu and polio epidemics of the time, psychiatrists, neurosurgeons and psychologists saw the growing numbers of inpatients, most of them hopeless cases. Most of these long-term patients were housed in state facilities, where care was not always at the standard one would expect in the United States. Moniz, and to a greater extent Freeman, showed what they viewed as a safe and simple means of stopping or easing the symptoms, so that formerly chronic patients could leave the institutions.

For Freeman, the new symptoms of frontal damage might change the lifestyle of a previously 'normal' individual, such as Joe A., but for those with schizophrenia, the frontal damage cost less than leaving the patients in the full grasp of schizophrenia. The medical community discovered that frontal and transorbital lobotomies did not stop the hallucinations and delusional thinking, but found the procedures ended much of the anxiety and depression and some bizarre behaviors, and generally, the patients were easier to handle. Some did come home - but not to the lives of the 'normal'.

This author remains concerned that clear indications for psychosurgery were not established, nor who should carry it out. Freeman had his ideas, and many tried their own experiments, without the benefit of empirical support. Perhaps this paved the way for institutional abuse. Freeman developed the transorbital lobotomy for its 
ease, with psychiatrists in mind. Although they treated people differently and often had very different types of patients, psychiatrists and neurosurgeons often trained together, and occasionally found themselves working together. Back then, medical organizations considered them two wings of a common area.

Although Pressman and El-Hai offer superb studies of the psychosurgery movement, the final word has yet to be written. El-Hai has given us the definitive biography of Walter Freeman, but the stories of James Watts and Egas Moniz remain unwritten. Undoubtedly, someone will attempt the task. One hopes that the scholars will be careful and considerate.

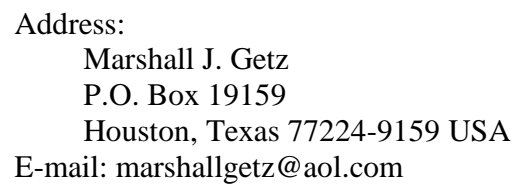

\section{References}

Alexander, Franz G. and Sheldon T. Selesnick (1966) The history of psychiatry: an evaluation of psychiatric thought and practice from prehistoric times to the present. New York: Harper \& Row.

Arai, Yoshifumi, Yoshihiro Tsutsui, Yuichiro Shinmura, Tomoki Kosugi, Hirofumi Nishikage, and Junnosuke Yamamoto (2001) "Case report: an autopsy case of the schizophrenic 32 years after lobotomy". Neuropathology 21, 53-60.

Associated Press (2005) "Rosemary Kennedy, senator's sister, 86, dies". The New York Times, January 8. Retrieved June 11, 2008 from http://www.nytimes.com.

Bender, Morris B. (1973) "Neurology at Mount Sinai". The Spectrum 3, unpaged. Retrieved March 13, 2005 from http://www.mssm.edu/neurology/introduction.shtml.

Braslow, Joel (1997) Mental ills and bodily cures: psychiatric treatment in the first half of the twentieth century. Berkeley: University of California Press.

Braslow, Joel (1999) "Where biopsychiatry came from: a short history of somatic therapies from 1900 to the 1950s". Harvard Mental Health Letter August, 16, 5. Retrieved January 24, 2005 from EBSCOhost.

Chavkin, Samuel (1978) The mind stealers: psychosurgery and mind control. Boston: Houghton Mifflin.

Cleveland Clinic Foundation (2005) "Calming the chaos: rewiring the brain through neuromodulation". Cleveland Clinic Magazine Winter, 22-26.

Clifford, Graeme, director (1982) Frances. United States: Motion picture.

Dallek, Robert (2003) An unfinished life: John F. Kennedy, 1917-1963. Boston: Little, Brown and Company.

Damasio, Antonio R (2000) Descartes' error: emotion, reason, and the human brain. New York: Quill (originally published 1994).

Diefenbach, Gretchen J., Donald Diefenbach, Alan Baumeister, and Mark West (1999) "Portrayal of lobotomy in the popular press: 1935-1960," Journal of the History of the Neurosciences 8, $60-69$.

Eisenberg, Leon (1998) "[Review of the book Last resort: Psychosurgery and the limits of medicine]". The New England Journal of Medicine December 3, 339, 1719-1720.

El-Hai, Jack (2005) The lobotomist: a maverick medical genius and his tragic quest to rid the world of mental illness. Hoboken, New Jersey: John Wiley \& Sons. 
Farmer, Frances (1972) Will there really be a morning? An autobiography. New York: Putnam. Fleischman, John (2002) Phineas Gage: a gruesome but true story about brain science. Boston: Houghton Mifflin.

Freeman, Walter (1949a) "Mass action versus mosaic function of the frontal lobe". Journal of Nervous \& Mental Disease 110, 413-418.

Freeman, Walter (1949b) “Transorbital lobotomy”. American Journal of Psychiatry 105, 734-740.

Freeman, Walter (1950) "Psychosurgery". American Journal of Psychiatry 106, 534-535.

Freeman, Walter (1957) "Frontal lobotomy 1936-1956: a follow-up study of 3000 patients from one to twenty years". American Journal of Psychiatry 113, 877-886.

Freeman, Walter (1967) "Multiple lobotomies". American Journal of Psychiatry 123, 1450-1452.

Freeman, Walter and James W. Watts (1950) Psychosurgery in the treatment of mental disorders and intractable pain. 2 nd ed. Springfield, Illinois: Charles C. Thomas.

González, Elizabeth Rasche (1980a) "Pain in men vs women". Journal of the American Medical Association November 14, 244, 2147.

González, Elizabeth Rasche (1980b) "Psychosurgery: waiting to make a comeback?". Journal of the American Medical Association November 21, 244, 2245-2247, 2250-2251.

González, Elizabeth Rasche (1980c) "Treating the brain by cingulotomy". Journal of the American Medical Association November 14, 244, 2141-2143, 2146-2147.

Gooding, Diane C., William G. Iacono, and Daniel R. Hanson (1999) "Smooth pursuit and saccadic eye movement performance in a prefrontal leukotomy patient". Journal of Psychiatry \& Neuroscience 24, 462-467. Retrieved January 24, 2005 from EBSCOhost.

Harvard Medical School (1996) "In memoriam: H. Thomas Ballantine, Jr.". May 10. Retrieved February 18, 2005 from http://focus.hms.harvard.edu/1996/May10_1996/InMemoriam.

HUBIN (2002) "Fever and cramp therapies". Human Brain Informatics, Department of Clinical Neuroscience, Karolinska Institutet (Sweden). Retrieved April 28, 2005, from http://www.hubin.org/facts/history/1900_history/treatment/treatment_4_en.html.

Jankovic, Joseph (2001) “Tourette's syndrome”. The New England Journal of Medicine October 18, $345,1184-1192$.

Kalinowsky, Lothar B., Hanns Hippius, and Helmfried E. Klein (1982) Biological treatments in psychiatry. New York: Grune and Stratton.

Kuehn, Bridget M. (2007) "Scientists probe deep brain stimulation: some promise for brain injury, psychiatric illness". Journal of the American Medical Association November 21, 298, 2249 2251.

Lamberts, A. E. (2000) "A most unusual case: what made the caged bird sing?". Cortlandt Forum August 25, 13, 87. Retrieved January 24, 2005 from EBSCOhost.

Ljunggren, Bengt, George Bruyn, Ilo Käbin, and Michael Buchfelder (1998) "Ludvig Puusepp founder of Estonian neurosurgery and Harvey Cushing's Eastern Hemisphere counterpart". Neurosurgery Quarterly 8, 2, 261-270.

Lowis, George W. and Alireza Minagar (2003) "The neglected research of Egas Moniz of internal carotid artery (ICA) occlusion". Journal of the History of the Neurosciences 12, 286-291.

Macmillan, Margaret (2003) Paris 1919: six months that changed the world. New York, Random House Trade.

Menand, Louis (2008) “The Pound error (Books)”. The New Yorker June 9. Retrieved June 11, 2008 from http://www.newyorker.com/arts/critics/books/2008/06/09.

Missouri Western Library (s.a.) Women writers along the rivers: Mary Frances Robinson (18921964). Retrieved April 10, 2005, from http://www.mwsc.edu/library/wwp/robinson.html.

Moniz, Egas (1994) "Prefrontal leucotomy in the treatment of mental disorders". American Journal of Psychiatry (Sesquicentennial Supplement) 151, 236-239 (original work published 1937).

Moore, Matthew T. (1949) "A new instrument for performing transorbital leucotomy". American Journal of Psychiatry 105, 741, plates 9 and 10.

Oltman, Jane E., Bernard S. Brody, Samuel Friedman, and William F. Green (1949) "Frontal lobotomy: clinical experience with 107 cases in a state hospital". American Journal of Psychiatry 105, 742-751. 
Pressman, Jack D. (1998) Last resort: psychosurgery and the limits of medicine. Cambridge, UK and New York: Cambridge University Press.

RadiologyInfo (2008) “Gamma Knife”. Retrieved April 18, 2009 from http://www.radiologyinfo.org/ en/info.cfm?pg=gamma_knife.

Rainie, Harrison and Katia Hetter (1993) "The most lasting Kennedy legacy". U.S. News \& World Report November 15, 115, 44. Retrieved January 24, 2005 from EBSCOhost.

Raudam, Ernst and Ain-Elmar Kaasik (1981) “Ludvig Puusepp 1875-1942”. Surgical Neurology 16, $2,85-87$.

Raudam, Ernst and Ain-Elmar Kaasik (1985) "Ludvig Puusepp 1875-1942”. In Paul C. Bucy, ed. Neurosurgical giants: feet of clay and iron, 283-287. New York: Elsevier.

Rollin, H. R. (2000) "Psychiatry at 2000: a bird's-eye view (opinion and debate)". Psychiatric Bulletin 24, 11-15. Retrieved February 18, 2005, from http://pb.rcpsych.org/cgi/content/ full/24/1/11.

Sabbatini, R. M. E. (1997-1998) "Manfred J. Sakel: a brief biography". [Electronic version.] Brain \& Mind Magazine December 1997-March 1998. Retrieved April 28, 2005, from http://www.cerebromente.org.br/n04/historia/sakel_i.htm.

Sakel, Manfred (1958) Schizophrenia. New York: Philosophical Library.

Schrader, Paul J. and Mary Frances Robinson (1945) "An evaluation of prefrontal lobotomy through ward behavior". Journal of Abnormal Psychology 40, 61-69.

Specter, Michael (2001) "Rethinking the brain". The New Yorker July 23, 42-53.

Strecker, Edward A. and Franklin G. Ebaugh (1928) Practical clinical psychiatry for students and practitioners. 2nd ed. Philadelphia: P Blakiston's.

Valenstein, Elliot S. (1973) Brain control: a critical examination of brain stimulation and psychosurgery. New York: Wiley-Interscience.

Volkmar, Fred R. (1999) "Lessons from secretin [Letter to the editor]". The New England Journal of Medicine December 9, 341, 1842-1844.

Whitaker, Robert (2002) Mad in America: bad science, bad medicine, and the enduring mistreatment of the mentally ill. New York: Basic Books.

Wiarda, Howard J. (1977) Corporatism and development: the Portuguese experience. Amherst: University of Massachusetts Press.

Wilkinson, Harold A. (2009) "Cingulotomy [Letter to the editor]". Journal of Neurosurgery 110, 607.

Wilmer, Clive (s.a.) "Pound's life and career". In Modern American poetry. Cary Nelson, ed. Retrieved June 11, 2008 from http://www.english.uiuc.edu/maps/poets/m_r/pound/bio.htm.

Yomo, Shoji, Yasser Arkha, Anne Donnet and Jean Régis (2009) "Gamma Knife surgery for glossopharyngeal neuralgia”. Journal of Neurosurgery 110, 3, 559-563. 